\title{
MENS-associated Increase of Muscular Protein Content Via Modulation of Caveolin-3 and TRIM72
}

\author{
Y. OHNO ${ }^{1}$, T. EGAWA ${ }^{2}$, S. YOKOYAMA ${ }^{1}$, H. FUJIYA ${ }^{3}$, T. SUGIURA ${ }^{4}$, Y. OHIRA ${ }^{5}$, \\ T. YOSHIOKA ${ }^{6}$, K. GOTO ${ }^{1,2}$
}

${ }^{1}$ Laboratory of Physiology, School of Health Sciences, Toyohashi SOZO University, Toyohashi, Japan, ${ }^{2}$ Department of Physiology, Graduate School of Health Sciences, Toyohashi SOZO University, Toyohashi, Japan, ${ }^{3}$ Department of Sports Medicine, St. Marianna University School of Medicine, Kawasaki, Japan, ${ }^{4}$ Faculty of Education, Yamaguchi University, Yamaguchi, Japan, ${ }^{5}$ Graduate School of Health and Sports Science, Doshisha University, Kyotanabe, Japan, ${ }^{6}$ Hirosaki Gakuin University, Hirosaki, Japan

Received July 27, 2018

Accepted October 29, 2018

Epub Ahead of Print January 10, 2019

\begin{abstract}
Summary
Microcurrent electrical neuromuscular stimulation (MENS) is known as an extracellular stimulus for the regeneration of injured skeletal muscle in sports medicine. However, the effects of MENS-associated increase in muscle protein content are not fully clarified. The purpose of this study was to investigate the effects of MENS on the muscular protein content, intracellular signals, and the expression level of caveolin-3 (Cav-3), tripartite motifcontaining 72 (TRIM72) and MM isoenzyme of creatine kinase (CK-MM) in skeletal muscle using cell culture system. C2C12 myotubes on the $7^{\text {th }}$ day of differentiation phase were treated with MENS (intensity: 10-20 $\mu \mathrm{A}$, frequency: $0.3 \mathrm{~Hz}$, pulse width: $250 \mathrm{~ms}$, stimulation time: 15-120 min). MENS-associated increase in the protein content of myotubes was observed, compared to the untreated control level. MENS upregulated the expression of Cav-3, TRIM72, and CK-MM in myotubes. A transient increase in phosphorylation level of Akt was also observed. However, MENS had no effect on the phosphorylation level of p42/44 extracellular signal-regulated kinase-1/2 and 5'AMP-activated protein kinase. MENS may increase muscle protein content accompanied with a transient activation of Akt and the upregulation of Cav-3 and TRIM72.
\end{abstract}

\section{Key words}

Skeletal muscle cells - Microcurrent electrical neuromuscular stimulation • Protein content • Caveolin-3 • Tripartite motifcontaining 72

\begin{abstract}
Corresponding author
K. Goto, Department of Physiology, Graduate School of Health Sciences, Toyohashi SOZO University, 20-1 Matsushita, Ushikawa, Toyohashi, Aichi 440-8511, Japan. E-mail: gotok@sepia.ocn.ne.jp
\end{abstract}

\section{Introduction}

Skeletal muscle injury is a most common sport trauma during sports activities. Various stimuli are proposed to facilitate the regeneration of injured skeletal muscle (Assis et al. 2013, Fujita et al. 2014, Nagata et al. 2013, Richard-Bulteau et al. 2008, Shibaguchi et al. 2016). Especially, electrical stimulation of injured muscle is used for more than 70 years (Gutmann and Guttmann 1944), and then the positive effects of electrical stimulation on skeletal muscle have been obtained. Even though recent evidences demonstrate that microcurrent electrical neuromuscular stimulation (MENS), which is an electrical stimulation causing no muscle contraction, facilitates skeletal muscle regeneration (Fujiya et al. 2015, Ohno et al. 2013), the molecular mechanism of MENS-associated muscle regeneration remains unclear.

Increase in protein synthesis is the essential process during the regeneration of injured skeletal muscle (Jones 1982, Jones 1984, Kojima et al. 2007, Kubica et al. 2005), and is stimulated by mechanical stress induced 
by muscle contraction and stretch (Drummond et al. 2009, Morioka et al. 2008, You et al. 2012). On the other hand, protein synthesis in skeletal muscle cells is mediated by the intracellular signals, such as protein kinase B (Akt), p42/44 extracellular signal-regulated kinase-1/2 (ERK1/2), and 5'AMP-activated protein kinase (AMPK). The activation of Akt signaling, which is well known as a potent stimulator for protein synthesis (Rommel et al. 2001), induces muscle differentiation (Coolican et al. 1997) and hypertrophy (Bodine et al. 2001, Sugiura et al. 2005). ERK1/2 signaling also stimulates muscle cell proliferation (Coolican et al. 1997) and differentiation (Li and Johnson 2006). Furthermore, it has been reported that AMPK signaling, which is a mediator for cellular energy balance, negatively regulates muscle mass via suppression of protein synthesis (Egawa et al. 2014, Sanchez et al. 2012). Although MENS stimulates the increase in protein content of atrophied and injured skeletal muscle (Fujiya et al. 2015, Ohno et al. 2013), the effects of MENS on Akt, ERK1/2, and AMPK in skeletal muscle cells are still unknown.

Caveolin-3 (Cav-3), which is an integral membrane protein, is expressed in muscle cells such as skeletal, cardiac, and smooth muscle cells (Song et al. 1996, Tang et al. 1996, Way and Parton 1996). Expression of Cav-3 is gradually upregulated during the differentiation of $\mathrm{C} 2 \mathrm{C} 12$ cells (Fanzani et al. 2007, Galbiati et al. 1999). In addition, the upregulation of Cav-3 is observed in regrowing slow soleus muscle (Ohno et al. 2014), hypertrophied C2C12 cells, and fast muscles (tibialis anterior, extensor digitorum longus, and thigh muscles) of mice (Fanzani et al. 2007), whereas an atrophic agent dexamethasone downregulates Cav-3 expression in C2C12 cells (Fanzani et al. 2007). Furthermore, overexpression of Cav-3 enhances protein synthesis and myotube hypertrophy in $\mathrm{C} 2 \mathrm{C} 12$ cells (Hadj Sassi et al. 2012). Therefore, the expression level of Cav-3 may be an indicator of protein synthesis that is regulated by hypertrophic and atrophic stimuli.

Cav-3 also plays a crucial role in repair of skeletal muscle membrane, interacting with tripartite motif-containing 72 (TRIM72) (Cai et al. 2009a, Cai et al. 2009b, Cai et al. 2009c). TRIM72 is expressed in the plasma membrane and intracellular vesicles of skeletal and cardiac muscle cells, and is one of TRIM family composed of a really interesting new gene finger domain, a B-box, two coiled coil domains, and a spla and ryanodine receptor domain (Cai et al. 2009a, Lee et al.
2010). TRIM72 is upregulated accompanying with myogenesis (Jung and Ko 2010, Lee et al. 2010, Yi et al. 2013). Recently, it was reported that TRIM72 was upregulated during regrowth of atrophied soleus muscle (Ohno et al. 2014). Even though MENS has facilitating effects on the regrowth of atrophied muscle and the regeneration of injured muscle (Fujiya et al. 2015, Ohno et al. 2013), there is no evidence regarding the effects of MENS on the expression of Cav-3 and TRIM72 in skeletal muscle. Furthermore, it has been also reported that Akt plays a mediator to regulate the expression of Cav-3 and TRIM72 in C2C12 cells (Fanzani et al. 2007, Lee et al. 2010).

In the present study, the effects of MENS on the muscular protein content, intracellular signals (Akt, ERK1/2, AMPK), and the expression level of Cav-3 and TRIM72 in skeletal muscle were investigated using cultured $\mathrm{C} 2 \mathrm{C} 12$ cells. In addition to the increases in Cav-3 and TRIM72 during muscle differentiation (Cai et al. 2009b, Fanzani et al. 2007, Lee et al. 2010), MM isoenzyme of creatine kinase (CK-MM) is known as a marker of myogenic differentiation (Chamberlain et al. 1985, Larraín et al. 1998). Therefore, we also investigated the change in CK-MM following MENS treatment.

\section{Methods}

\section{Cell culture}

Mouse myoblast $\mathrm{C} 2 \mathrm{C} 12$ cells $\left(6 \times 10^{4}\right.$ cells/well) were cultured on 6-well culture plates with type I collagen-coated surface (Biocoat, Corning Inc., Corning, NY, USA). Cells were maintained in $2 \mathrm{ml}$ of growth medium consisting of Dulbecco's modified Eagle's medium (DMEM; Thermo Fisher Scientific, Yokohama, Japan) supplemented with $10 \%$ heat-inactivated fetal bovine serum containing high glucose (4.5 g/l glucose, $4.0 \mathrm{mM} \mathrm{L}$-glutamine, without sodium pyruvate) for proliferation under a humidified atmosphere with $95 \%$ air and $5 \% \mathrm{CO}_{2}$. On the $3^{\text {rd }}$ day of the proliferation phase (at $\sim 80 \%$ confluence), the culture medium was then changed to same amount of differentiation medium consisting of DMEM supplemented with $2 \%$ heatinactivated horse serum containing low glucose $(1.0 \mathrm{~g} / \mathrm{l}$ glucose, $4.0 \mathrm{mM}$ L-glutamine, and $110 \mathrm{mg} / \mathrm{l}$ sodium pyruvate) for differentiation, as was described previously (Egawa et al. 2014). The differentiation medium was changed every 2 days and cultures were maintained for 8 days to form myotubes. 


\section{MENS}

MENS using an electrical stimulator (Trio300, Ito Co., Ltd., Tokyo, Japan) was delivered to the culture medium through platinum electrodes, which placed on opposing inside walls of a well (Fig. 1). The cells in a plate were simultaneously treated with MENS in a cell culture incubator $\left(37^{\circ} \mathrm{C}, \quad 5 \% \mathrm{CO}_{2}\right)$. Although the electrodes were also set in the medium of the untreated control cells in the same manner, no MENS was applied.

Experiment 1: Effects of MENS on protein content in C2C12 cells

First of all, we investigated whether the condition of MENS have effects on increase in protein content of skeletal muscle cells. The myotubes on the $7^{\text {th }}$ day of differentiation phase were treated with MENS, then the cells were collected $24 \mathrm{~h}$ after the application of MENS (Fig. 2A). The condition for MENS (intensity: 10 or $20 \mu \mathrm{A}$, frequency: $0.3 \mathrm{~Hz}$, pulse width: $250 \mathrm{~ms}$, duration: $0,15,30,60$, and $120 \mathrm{~min}, \mathrm{n}=8$ wells per group) was referred to the previous study that observed increase in muscular protein content in mouse skeletal muscle (Ohno et al. 2013). These conditions of MENS did not induce myotube contraction.

$\mathrm{C} 2 \mathrm{C} 12$ cells were lysed in cell lysis reagent (CelLytic ${ }^{\mathrm{TM}}-\mathrm{M}$, Sigma-Aldrich, St. Louis, MO, USA) with some modification of the previously reported method (Egawa et al. 2014) to extract total muscle protein from the cells. Briefly, the cells in each well were rinsed twice with $1 \mathrm{ml}$ of ice-cold phosphate-buffered saline. Then, the cells of each well were scraped into $0.3 \mathrm{ml}$ of cell lysis reagent on ice. The cell lysate was sonicated and centrifuged at $20,000 \mathrm{~g}$ at $4{ }^{\circ} \mathrm{C}$ for $10 \mathrm{~min}$. The supernatant was collected for the determination of protein content. Protein content in the supernatant was determined by the Bradford technique (Protein Assay Kit, Bio-Rad, Hercules, CA, USA) and bovine serum albumin (Sigma) as the standard. Protein content was expressed relative percentage to the value of untreated control group (0 $\mathrm{min})$.

Experiment 2: Effects of MENS on intracellular signals in C2C12 myotubes

According to the results of Experiment 1 and the previous study that observed changes in intracellular signals in mouse skeletal muscle (Ohno et al. 2013), the myotubes on $7^{\text {th }}$ days of differentiation phase were treated with MENS at $10 \mu \mathrm{A}$ for $60 \mathrm{~min}$ (frequency: $0.3 \mathrm{~Hz}$, pulse width: $250 \mathrm{~ms}$ ). The cells were collected 1,3 , and

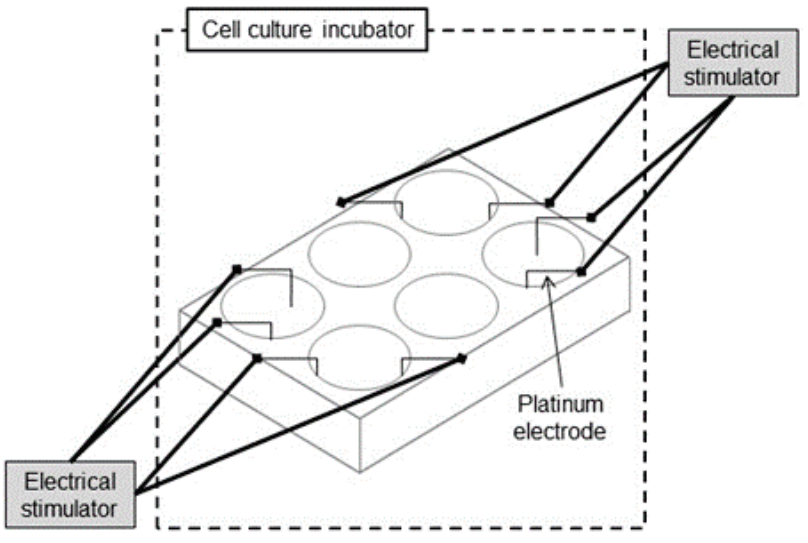

Fig. 1. An illustration of the setup for a 6-well plate treated with microcurrent electrical neuromuscular stimulation (MENS) treatment. MENS using an electrical stimulator (Trio300, Ito Co., Ltd., Tokyo, Japan) was delivered to the culture medium through platinum electrodes, which placed on opposing inside walls of a well. Cells on 4 wells of a 6 -well plate were stimulated by MENS. Other 2 wells of the plate were not used for MENStreatment group.

\section{A Experiment 1}

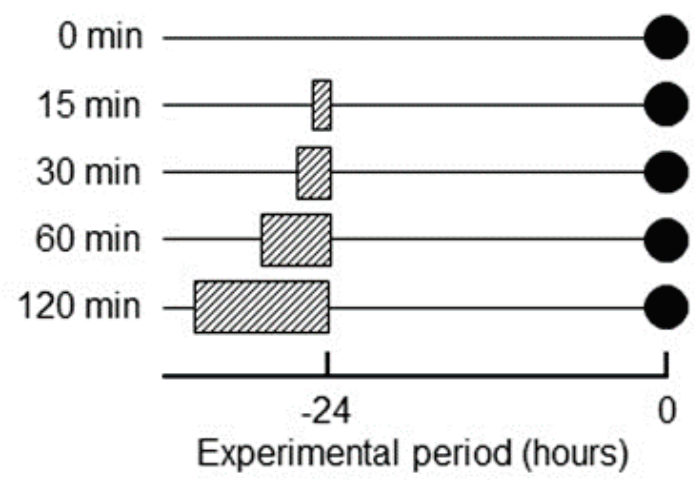

\section{B Experiment 2}

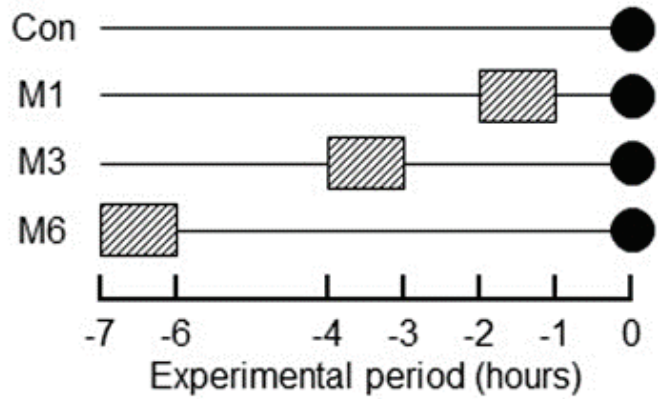

MENS-treatment

Sampling

Fig. 2. (A) Protocol for Experiment 1. MENS with 10-20 $\mu \mathrm{A}$ for 15-120 min were delivered to $\mathrm{C} 2 \mathrm{C} 12$ myotubes on the 7th day of differentiation phase. Thereafter, the cells were collected $24 \mathrm{~h}$ after MENS treatment. (B) Protocol for Experiment 2. MENS at $10 \mu \mathrm{A}$ for 60 min was delivered to $\mathrm{C} 2 \mathrm{C} 12$ myotubes on the 7th day of differentiation phase. Thereafter, the cells were collected 1 (M1), 3 (M3), and 6 h (M6) after MENS treatment. 
$6 \mathrm{~h}$ after the application of MENS ( $\mathrm{n}=8$ wells per group, Fig. 2B). In Experiment 2, we investigated the MENSassociated early responses $(1,3$, and $6 \mathrm{~h}$ after the stimulation) of the protein expression levels (Cav-3 and TRIM72) and the intracellular signals involved in muscle protein synthesis (Akt, ERK1/2, AMPK).

Western blot analysis was performed with some modification of the previously reported method (Egawa et al. 2014, Ohno et al. 2014). The cells were lysed in $0.3 \mathrm{ml}$ of cell lysis reagent (CelLytic ${ }^{\mathrm{TM}}-\mathrm{M}$, Sigma) with
$10 \%$ (v/v) Protease Inhibitor Cocktail (P8340, Sigma) and $1 \%(\mathrm{v} / \mathrm{v})$ Phosphatase Inhibitor Cocktail (524625, Calbiochem, San Diego, CA, USA) and centrifuged. Then the supernatant was collected. After the determination of protein content in the supernatant, the supernatant samples were mixed with sodiumdodecylsulfate (SDS) sample buffer [30\% (v/v) glycerol, $5 \%(\mathrm{v} / \mathrm{v})$ 2-mercaptoethanol, $2.3 \%$ (w/v) SDS, $62.5 \mathrm{mM}$ Tris- $\mathrm{HCl}, 0.05 \%(\mathrm{w} / \mathrm{v})$ bromophenol blue and $\mathrm{pH} 6.8]$ and were boiled for $5 \mathrm{~min}$. The SDS-polyacrylamide gel
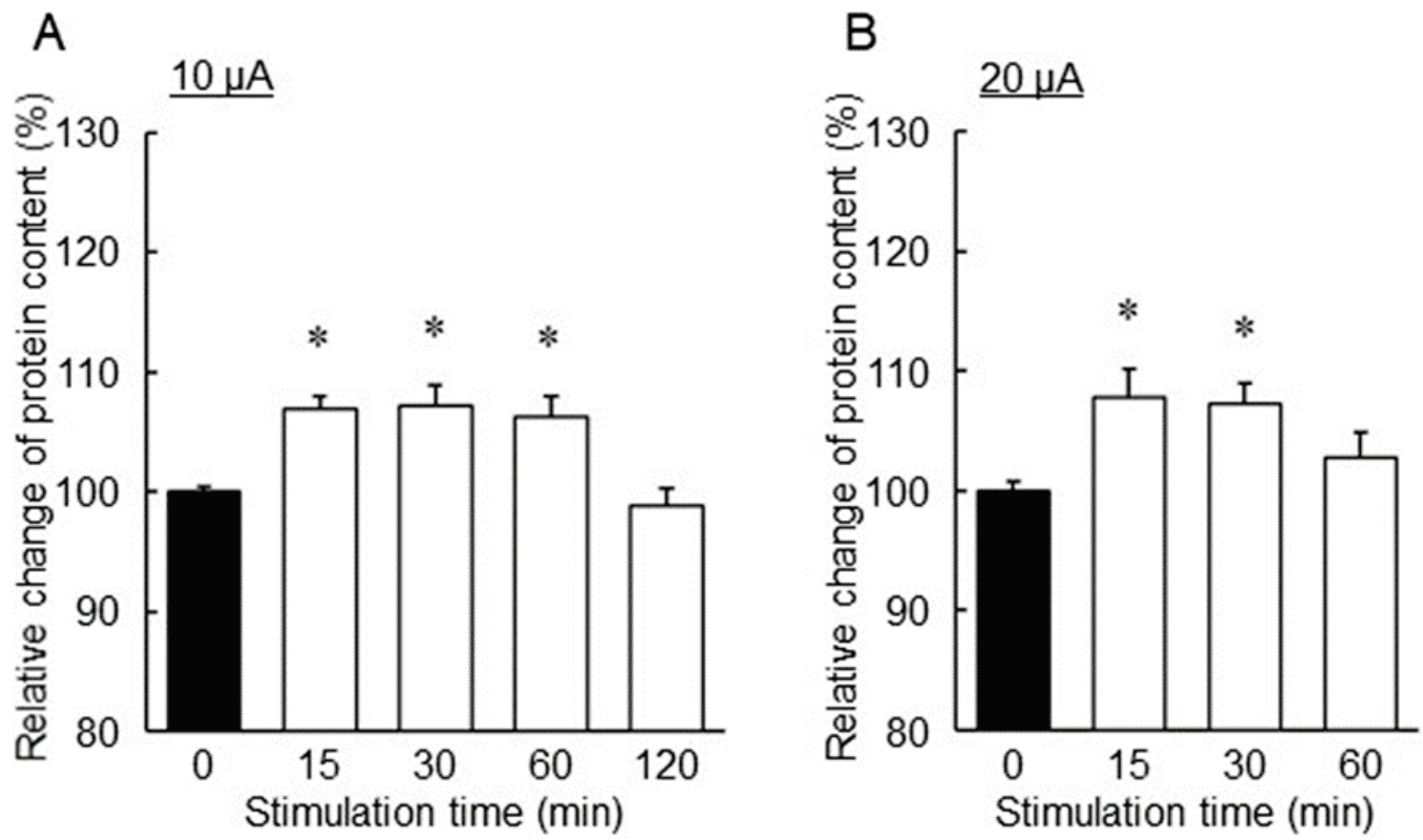

Fig. 3. Protein content in $\mathrm{C} 2 \mathrm{C} 12$ myotubes after MENS at $10 \mu \mathrm{A}(\mathbf{A})$ and $20 \mu \mathrm{A}(\mathbf{B})$. Values are expressed as relative percentage to the value of 0 min (untreated control). Values are means $\pm S E M, n=8$ wells per group, * significant different from 0 min, $p<0.05$.
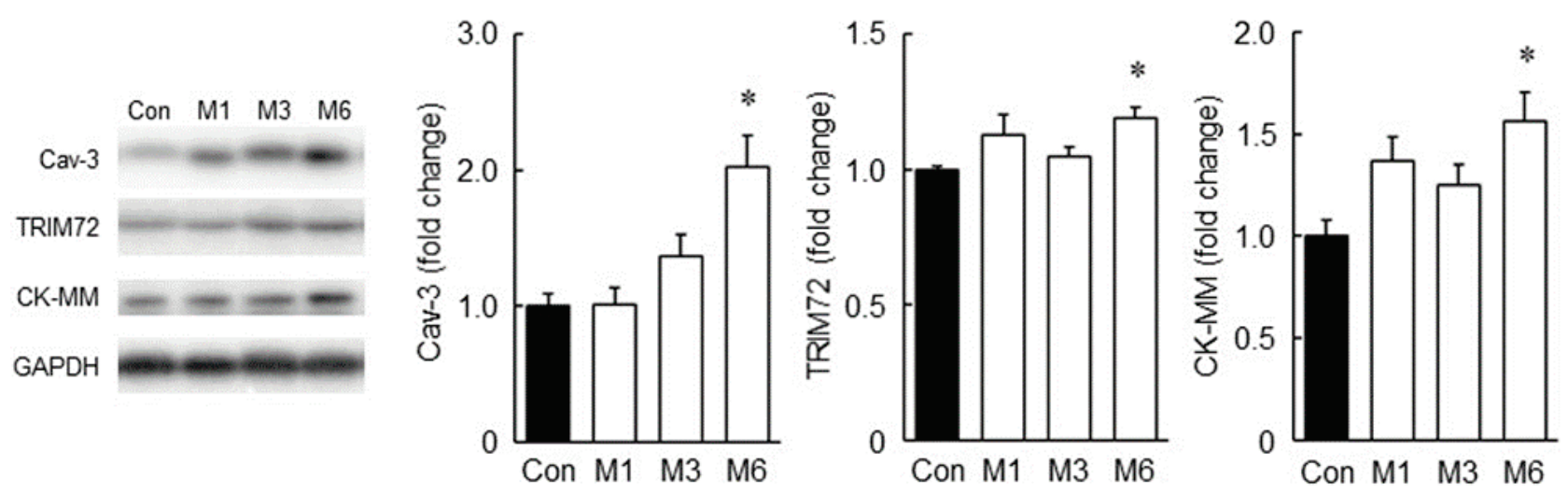

Fig. 4. Effects of MENS at $10 \mu \mathrm{A}$ for $60 \mathrm{~min}$ on the expression level of Cav-3, TRIM72, and CK-MM in C2C12 myotubes. Con: untreated control group; Cav-3: caveolin-3; TRIM72: tripartite motif-containing 72; CK-MM: MM isoenzyme of creatine kinase; GAPDH: glyceraldehyde-3-phosphate dehydrogenase. See Fig. 2 for other abbreviations. Values are expressed relative to the value of Con. Values are means \pm SEM, $n=8$ wells per group, * significant different from Con, $\mathrm{p}<0.05$. 

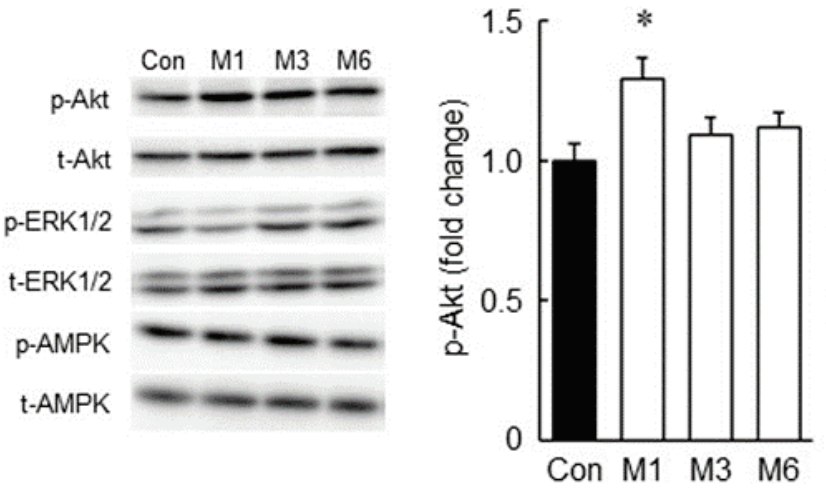
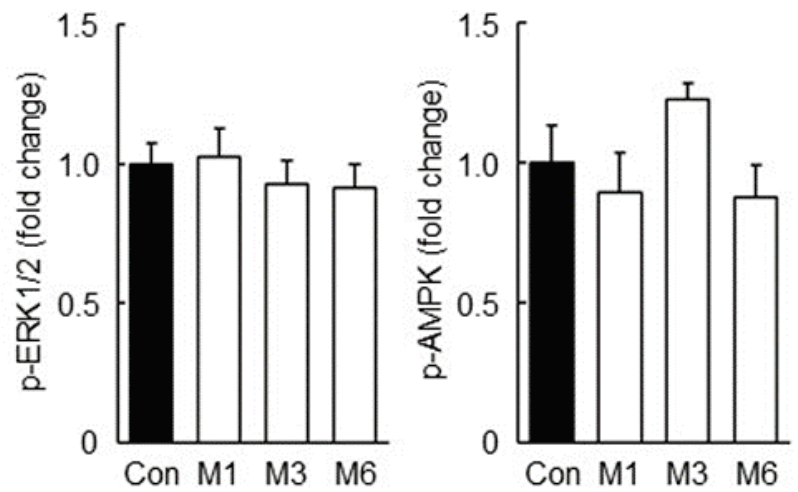

Fig. 5. Effects of MENS at $10 \mu \mathrm{A}$ for $60 \mathrm{~min}$ on the phosphorylation level of Akt, ERK1/2, and AMPK in C2C12 myotubes. p-Akt: phosphorylated Akt; t-Akt: total Akt; $p$-ERK1/2: phosphorylated p42/44 extracellular signal-regulated kinase (ERK)-1/2; t-ERK1/2: total ERK1/2; p-AMPK: phosphorylated 5'AMP-activated protein kinase (AMPK)a; t-AMPK: total AMPKa. See Figs 2 and 4 for other abbreviations. Values are expressed relative to the value of Con. Values are means $\pm S E M, n=8$ wells per group, * significant different from Con, $p<0.05$.

electrophoresis (PAGE) was carried out on 8-12\% polyacrylamide containing $0.5 \% \mathrm{SDS}$ at a constant current of $20 \mathrm{~mA}$ for $120 \mathrm{~min}$. Equal amounts of protein $(8 \mu \mathrm{g})$ were loaded on each gel. Molecular weight markers (Bio-Rad Precision Markers) were applied to both sides of gel as the internal controls for transfer process or electrophoresis.

Following SDS-PAGE, proteins were transferred to polyvinylidene difluoride membranes (Bio-Rad) using a Bio-Rad mini trans-blot cell at a constant voltage of 100 $\mathrm{V}$ for $60 \mathrm{~min}$ at $4{ }^{\circ} \mathrm{C}$. After the transfer, the membranes were blocked for $1 \mathrm{~h}$ using a skim milk. Then, the membranes were incubated for $2 \mathrm{~h}$ with a primary antibody: Cav-3 (ab2912, Abcam, Cambridge, UK), TRIM72 (PAB18940, Abnova, Taipei, Taiwan), CK-MM (ab198235, Abcam), phosphorylated Akt at $\mathrm{Ser}^{473}$ residue (p-Akt: 9271, Cell Signaling Technology Inc., Danvers, Mass., USA), total Akt (t-Akt: 9272, Cell Signaling), phosphorylated ERK1/2 at $\mathrm{Thr}^{202} / \mathrm{Tyr}^{204}$ residue (p-ERK1/2: 9101, Cell Signaling), total ERK1/2 (t-ERK1/2: 9102, Cell Signaling), phosphorylated AMPK $\alpha$ at $\mathrm{Thr}^{172}$ residue (p-AMPK: 2531, Cell Signaling), total AMPK $\alpha$ (t-AMPK: 2532, Cell Signaling), GAPDH (G9545, Sigma) and then reacted with a secondary antibody: anti-goat or anti-rabbit immunoglobulin $\mathrm{G}$ conjugate to horseradish peroxidase for $2 \mathrm{~h}$. After the final wash, protein bands were visualized using chemiluminescence (GE Healthcare, Buckinghamshire, UK), and signal density was measured using Light-Capture (AE-6971) with CS Analyzer version 2.08b (ATTO Corporation, Tokyo, Japan).

\section{Statistical analysis}

All values were expressed as means \pm SEM.
Statistical significance was analyzed by one-way analysis of variance followed by Dunnett test. The significance level was accepted at $\mathrm{p}<0.05$.

\section{Results}

Experiment 1: Effect of MENS on protein content in C2C12 cells

In the present study, we examined the effects of MENS on the protein content of $\mathrm{C} 2 \mathrm{C} 12$ myotubes. The cells were collected $24 \mathrm{~h}$ after the application of MENS (intensity: 10 or $20 \mu \mathrm{A}$, duration: 0-120 min, Fig. 2A) for the evaluation of protein content. Figs $3 \mathrm{~A}$ and $\mathrm{B}$ show the protein content in $\mathrm{C} 2 \mathrm{C} 12$ myotubes $24 \mathrm{~h}$ after MENS treatment at $10(\mathrm{~A})$ and $20 \mu \mathrm{A}(\mathrm{B})$, respectively. MENS with $10 \mu \mathrm{A}$ for $15-60 \mathrm{~min}$ significantly increased the protein content of myotubes, compared to the untreated control level $(\mathrm{p}<0.05)$. Overall response of protein content after MENS treatment at $20 \mu \mathrm{A}$ was similar to that at $10 \mu \mathrm{A}$. MENS with $20 \mu \mathrm{A}$ for 15-30 min significantly increased the protein content of the myotubes $(\mathrm{p}<0.05)$. However, MENS with $10 \mu \mathrm{A}$ for $120 \mathrm{~min}$ or $20 \mu \mathrm{A}$ for $60 \mathrm{~min}$ had no impact on the protein content.

\section{Experiment 2: Effect of MENS on intracellular signals}

Since we confirmed that MENS-associated increase in the protein content of $\mathrm{C} 2 \mathrm{C} 12$ myotubes was observed $24 \mathrm{~h}$ after the treatment, the effects of MENS with $10 \mu \mathrm{A}$ for $60 \mathrm{~min}$ on the expression level of Cav-3 and TRIM72 were investigated in myotubes. The cells were collected 1, 3, and $6 \mathrm{~h}$ after the application of MENS (Fig. 2B) for western blot analyses. Fig. 4 shows the responses of Cav-3, TRIM72, and CK-MM to MENS 
in $\mathrm{C} 2 \mathrm{C} 12$ myotubes. MENS increased the expression of Cav-3, TRIM72, and CK-MM in myotubes. The expression level of Cav-3, TRIM72, and CK-MM $6 \mathrm{~h}$ after MENS treatment was significantly increased, compared to the untreated control level $(p<0.05)$. In addition, we investigated the effects of MENS on the phosphorylated level of Akt, ERK1/2, and AMPK $\alpha$ in myotubes (Fig. 5). A transient increase in the relative expression level of $\mathrm{p}$-Akt was observed $1 \mathrm{~h}$ after MENS treatment, compared to the untreated control level $(p<0.05)$. However, there was no significant change in the p-Akt level 3 and $6 \mathrm{~h}$ after MENS treatment. On the other hand, MENS had no effects on the level of p-ERK1/2 and p-AMPK $\alpha$ in myotubes.

\section{Discussion}

The present study demonstrated that MENSassociated increase of protein content in $\mathrm{C} 2 \mathrm{C} 12$ myotubes accompanied with the upregulation of CK-MM, Cav-3, and TRIM72, and with a transient increase in phosphorylated form of Akt. On the other hand, MENS had no effects on the phosphorylation levels of ERK1/2 and $\mathrm{AMPK} \alpha$ in $\mathrm{C} 2 \mathrm{C} 12$ myotubes. This is the first report showing the effects of MENS on the total protein content, the expression level of Cav-3, TRIM72, and CK-MM proteins, and the intracellular signals in myotubes.

Upregulation of Cav-3, TRIM72, and CK-MM proteins in myotubes was observed following MENS treatment in the present study. It is reported that the upregulation of Cav-3 and TRIM72 is observed during differentiation of C2C12 cells (Cai et al. 2009b, Fanzani et al. 2007, Lee et al. 2010), and during reloadingassociated muscle regrowth (Ohno et al. 2014), in hypertrophied myotubes induced by transfection of an activated form of Akt (Fanzani et al. 2007). Furthermore, MENS-associated upregulation of CK-MM, which is a maker of myogenic differentiation (Chamberlain et al. 1985, Larraín et al. 1998), was also observed. These observations indicate that MENS has a stimulating effect on myogenic differentiation.

In the present study, the protein content in myotubes was increased by MENS. This result is supported by the previous studies that MENS facilitated regrowth of atrophied and injured skeletal muscle in mice (Fujiya et al. 2015, Ohno et al. 2013). On the other hand, MENS with $10 \mu \mathrm{A}$ for $120 \mathrm{~min}$ or $20 \mu \mathrm{A}$ for $60 \mathrm{~min}$ had no impact on the protein content. Therefore, there is a possibility that the appropriate dosage (stimulation intensity $\mathrm{x}$ duration) of MENS may exist, although we cannot explain the difference in the response to stimulus parameter of MENS at present. Additional experiments are required to elucidate this issue. It is suggested that the overexpression of Cav-3 shows the enhanced protein synthesis via the downregulation of myostatin in $\mathrm{C} 2 \mathrm{C} 12$ cells (Hadj Sassi et al. 2012). Furthermore, in the present study, the transient and significant activation of Akt in myotubes was induced by MENS. This result is also consistent with the results from the previous study that MENS-associated upregulation of p-Akt expression was observed in mouse soleus muscle (Ohno et al. 2013). Since Akt plays a key role in intracellular signaling of protein synthesis in skeletal muscle (Bodine et al. 2001, Sugiura et al. 2005) as well as the expression of Cav-3 and TRIM72 in C2C12 cells (Fanzani et al. 2007, Lee et al. 2010), MENS-associated increase of protein content accompaying with the up-regulation of Cav-3 and TRIM72 in myotubes might be attributed to the activation of Akt. Further investigation is necessary to clarify precise role of Akt in muscle protein synthesis in response to MENS.

On the other hand, there were no significant changes in $\mathrm{p}$-ERK $1 / 2$ and $\mathrm{p}$-AMPK $\alpha$ in response to MENS in the present study. The phosphorylation level of ERK1/2 and AMPK $\alpha$ is upregulated after electricallyinduced muscle contraction (Treebak et al. 2006, Wojtaszewski et al. 1999). As MENS induces no muscle contraction, MENS might have no effects on the signaling pathways of ERK $1 / 2$ and AMPK $\alpha$. Additional experiments should be needed to explain this issue.

In conclusion, MENS may have a stimulating effect on muscle protein content in accompany with the upregulation of Cav-3 and TRIM72, and with a transient activation of Akt. Evidences from this study suggest that MENS stimulates not only protein synthesis but also membrane repair in the regeneration of injured skeletal muscle. MENS could be a potentially useful tool for injured athletes in sports medicine as well as rehabilitation.

\section{Conflict of Interest}

The authors have declared that no conflicts of interest exist.

\section{Acknowledgements}

Authors thank Dr. L. L. Tang of Department of Physiology, Graduate School of Health Sciences, Toyohashi SOZO University for his technical assistance. 
This study was supported, in part, by Grants-in-Aid for challenging Exploratory Research (16K12942, Y. Ohno; 16K13022, K.G.), and Grants-in-Aid for Scientific Research (C, 26350818, T.Y.) from the Japan Society for the Promotion of Science, the Uehara Memorial
Foundation (Y. Ohno; K.G.), the Naito Foundation (K.G.), the Descente Sports Foundation, the All Japan Coffee Association, and Graduate School of Health Sciences, Toyohashi SOZO University (K.G.).

\section{References}

ASSIS L, MORETTI AI, ABRAHÃO TB, DE SOUZA HP, HAMBLIN MR, PARIZOTTO NA: Low-level laser therapy $(808 \mathrm{~nm})$ contributes to muscle regeneration and prevents fibrosis in rat tibialis anterior muscle after cryolesion. Lasers Med Sci 28: 947-955, 2013.

BODINE SC, STITT TN, GONZALEZ M, KLINE WO, STOVER GL, BAUERLEIN R, ZLOTCHENKO E, SCRIMGEOUR A, LAWRENCE JC, GLASS DJ, YANCOPOULOS GD: Akt/mTOR pathway is a crucial regulator of skeletal muscle hypertrophy and can prevent muscle atrophy in vivo. Nat Cell Biol 3: 1014-1019, 2001.

CAI C, MASUMIYA H, WEISLEDER N, MATSUDA N, NISHI M, HWANG M, KO JK, LIN P, THORNTON A, ZHAO X, PAN Z, KOMAZAKI S, BROTTO M, TAKESHIMA H, MA J: MG53 nucleates assembly of cell membrane repair machinery. Nat Cell Biol 11: 56-64, 2009a.

CAI C, MASUMIYA H, WEISLEDER N, PAN Z, NISHI M, KOMAZAKI S, TAKESHIMA H, MA J: MG53 regulates membrane budding and exocytosis in muscle cells. J Biol Chem 284: 3314-3322, 2009b.

CAI C, WEISLEDER N, KO JK, KOMAZAKI S, SUNADA Y, NISHI M, TAKESHIMA H, MA J: Membrane repair defects in muscular dystrophy are linked to altered interaction between MG53, caveolin-3, and dysferlin. $J$ Biol Chem 284: 15894-15902, 2009c.

CHAMBERLAIN JS, JAYNES JB, HAUSCHKA SD: Regulation of creatine kinase induction in differentiating mouse myoblasts. Mol Cell Biol 5: 484-492, 1985.

COOLICAN SA, SAMUEL DS, EWTON DZ, MCWADE FJ, FLORINI JR: The mitogenic and myogenic actions of insulin-like growth factors utilize distinct signaling pathways. $J$ Biol Chem 272: 6653-6662, 1997.

DRUMMOND MJ, FRY CS, GLYNN EL, DREYER HC, DHANANI S, TIMMERMAN KL, VOLPI E, RASMUSSEN BB: Rapamycin administration in humans blocks the contraction-induced increase in skeletal muscle protein synthesis. $J$ Physiol 587: 1535-1546, 2009.

EGAWA T, OHNO Y, GOTO A, IKUTA A, SUZUKI M, OHIRA T, YOKOYAMA S, SUGIURA T, OHIRA Y, YOSHIOKA T, GOTO K: AICAR-induced activation of AMPK negatively regulates myotube hypertrophy through the HSP72-mediated pathway in C2C12 skeletal muscle cells. Am J Physiol Endocrinol Metab 306: E344-E354, 2014.

FANZANI A, MUSARÒ A, STOPPANI E, GIULIANI R, COLOMBO F, PRETI A, MARCHESINI S: Hypertrophy and atrophy inversely regulate Caveolin-3 expression in myoblasts. Biochem Biophys Res Commun 357: 314-318, 2007.

FUJITA N, ONO M, TOMIOKA T, DEIE M: Effects of hyperbaric oxygen at 1.25 atmospheres absolute with normal air on macrophage number and infiltration during rat skeletal muscle regeneration. PLoS One 9: e115685, 2014.

FUJIYA H, OGURA Y, OHNO Y, GOTO A, NAKAMURA A, OHASHI K, UEMATSU D, AOKI H, MUSHA H, GOTO K: Microcurrent electrical neuromuscular stimulation facilitates regeneration of injured skeletal muscle in mice. $J$ Sports Sci Med 14: 297-303, 2015.

GALBIATI F, VOLONTE D, ENGELMAN JA, SCHERER PE, LISANTI MP: Targeted down-regulation of caveolin-3 is sufficient to inhibit myotube formation in differentiating $\mathrm{C} 2 \mathrm{C} 12$ myoblasts. Transient activation of $\mathrm{p} 38$ mitogen-activated protein kinase is required for induction of caveolin-3 expression and subsequent myotube formation. J Biol Chem 274: 30315-30321, 1999.

GUTMANN E, GUTTMANN L: The effect of galvanic exercise on denervated and re-innervated muscles in the rabbit. J Neurol Psychiatry 7: 7-17, 1944. 
HADJ SASSI A, MONTEIL J, SAUVANT P, ATGIÉ C: Overexpression of caveolin-3-enhanced protein synthesis rather than proteolysis inhibition in $\mathrm{C} 2 \mathrm{C} 12$ myoblasts: relationship with myostatin activity. $J$ Physiol Biochem 68: 683-690, 2012.

JONES GH: Protein synthesis in bupivacaine (marcaine)-treated, regenerating skeletal muscle. Muscle Nerve 5: 281-290, 1982.

JONES GH: Time course of changes in protein synthesis in marcaine-induced skeletal muscle regeneration. Mech Ageing Dev 27: 373-381, 1984.

JUNG SY, KO YG: TRIM72, a novel negative feedback regulator of myogenesis, is transcriptionally activated by the synergism of MyoD (or myogenin) and MEF2. Biochem Biophys Res Commun 396: 238-245, 2010.

KOJIMA A, GOTO K, MORIOKA S, NAITO T, AKEMA T, FUJIYA H, SUGIURA T, OHIRA Y, BEPPU M, AOKI $\mathrm{H}$, YOSHIOKA T: Heat stress facilitates the regeneration of injured skeletal muscle in rats. J Orthop Sci 12: 74-82, 2007.

KUBICA N, BOLSTER DR, FARRELL PA, KIMBALL SR, JEFFERSON LS: Resistance exercise increases muscle protein synthesis and translation of eukaryotic initiation factor 2Bepsilon mRNA in a mammalian target of rapamycin-dependent manner. J Biol Chem 280: 7570-7580, 2005.

LARRAÍN J, CAREY DJ, BRANDAN E: Syndecan-1 expression inhibits myoblast differentiation through a basic fibroblast growth factor-dependent mechanism. J Biol Chem 273: 32288-32296, 1998.

LEE CS, YI JS, JUNG SY, KIM BW, LEE NR, CHOO HJ, JANG SY, HAN J, CHI SG, PARK M, LEE JH, KO YG: TRIM72 negatively regulates myogenesis via targeting insulin receptor substrate-1. Cell Death Differ 17: 1254-1265, 2010.

LI J, JOHNSON SE: ERK2 is required for efficient terminal differentiation of skeletal myoblasts. Biochem Biophys Res Commun 345: 1425-1433, 2006.

MORIOKA S, GOTO K, KOJIMA A, NAITO T, MATSUBA Y, AKEMA T, FUJIYA H, SUGIURA T, OHIRA Y, BEPPU M, AOKI H, YOSHIOKA T: Functional overloading facilitates the regeneration of injured soleus muscles in mice. J Physiol Sci 58: 397-404, 2008.

NAGATA K, NAKAMURA T, FUJIHARA S, TANAKA E: Ultrasound modulates the inflammatory response and promotes muscle regeneration in injured muscles. Ann Biomed Eng 41: 1095-1105, 2013.

OHNO Y, FUJIYA H, GOTO A, NAKAMURA A, NISHIURA Y, SUGIURA T, OHIRA Y, YOSHIOKA T, GOTO $\mathrm{K}$ : Microcurrent electrical nerve stimulation facilitates regrowth of mouse soleus muscle. Int J Med Sci 10: 1286-1294, 2013.

OHNO Y, SUGIURA T, OHIRA Y, YOSHIOKA T, GOTO K: Loading-associated expression of TRIM72 and caveolin-3 in antigravitational solues muscle in mice. Physiol Rep 2: e12259, 2014.

RICHARD-BULTEAU H, SERRURIER B, CRASSOUS B, BANZET S, PEINNEQUIN A, BIGARD X, KOULMANN N: Recovery of skeletal muscle mass after extensive injury: positive effects of increased contractile activity. Am J Physiol Cell Physiol 294: C467-C476, 2008.

ROMMEL C, BODINE SC, CLARKE BA, ROSSMAN R, NUNEZ L, STITT TN, YANCOPOULOS GD, GLASS DJ: Mediation of IGF-1-induced skeletal myotube hypertrophy by PI(3)K/Akt/mTOR and PI(3)K/Akt/GSK3 pathways. Nat Cell Biol 3: 1009-1013, 2001.

SANCHEZ AM, CANDAU RB, CSIBI A, PAGANO AF, RAIBON A, BERNARDI H: The role of AMP-activated protein kinase in the coordination of skeletal muscle turnover and energy homeostasis. Am J Physiol Cell Physiol 303: C475-C485, 2012.

SHIBAGUCHI T, SUGIURA T, FUJITSU T, NOMURA T, YOSHIHARA T, NAITO H, YOSHIOKA T, OGURA A, OHIRA Y: Effects of icing or heat stress on the induction of fibrosis and/or regeneration of injured rat soleus muscle. J Physiol Sci 66: 345-357, 2016.

SONG KS, SCHERER PE, TANG Z, OKAMOTO T, LI S, CHAFEL M, CHU C, KOHTZ DS, LISANTI MP: Expression of caveolin-3 in skeletal, cardiac, and smooth muscle cells. Caveolin-3 is a component of the sarcolemma and co-fractionates with dystrophin and dystrophinassociated glycoproteins. J Biol Chem 271: $15160-15165,1996$. 
SUGIURA T, ABE N, NAGANO M, GOTO K, SAKUMA K, NAITO H, YOSHIOKA T, POWERS SK: Changes in $\mathrm{PKB} / \mathrm{Akt}$ and calcineurin signaling during recovery in atrophied soleus muscle induced by unloading. Am $J$ Physiol Regul Integr Comp Physiol 288: R1273-R1278, 2005.

TANG Z, SCHERER PE, OKAMOTO T, SONG K, CHU C, KOHTZ DS, NISHIMOTO I, LODISH HF, LISANTI MP: Molecular cloning of caveolin-3, a novel member of the caveolin gene family expressed predominantly in muscle. J Biol Chem 271: 2255-2261, 1996.

TREEBAK JT, GLUND S, DESHMUKH A, KLEIN DK, LONG YC, JENSEN TE, JØRGENSEN SB, VIOLLET B, ANDERSSON L, NEUMANN D, WALLIMANN T, RICHTER EA, CHIBALIN AV, ZIERATH JR, WOJTASZEWSKI JF: AMPK-mediated AS160 phosphorylation in skeletal muscle is dependent on AMPK catalytic and regulatory subunits. Diabetes 55: 2051-2058, 2006.

WAY M, PARTON RG: M-caveolin, a muscle-specific caveolin-related protein. FEBS Lett 378: 108-112, 1996.

WOJTASZEWSKI JF, LYNGE J, JAKOBSEN AB, GOODYEAR LJ, RICHTER EA: Differential regulation of MAP kinase by contraction and insulin in skeletal muscle: metabolic implications. Am J Physiol 277: E724-E732, 1999.

YI JS, PARK JS, HAM YM, NGUYEN N, LEE NR, HONG J, KIM BW, LEE H, LEE CS, JEONG BC, SONG HK, CHO H, KIM YK, LEE JS, PARK KS, SHIN H, CHOI I, LEE SH, PARK WJ, PARK SY, CHOI CS, LIN P, KARUNASIRI M, TAN T, DUANN P, ZHU H, MA J, KO YG: MG53-induced IRS-1 ubiquitination negatively regulates skeletal myogenesis and insulin signalling. Nat Commun 4: 2354, 2013.

YOU JS, FREY JW, HORNBERGER TA: Mechanical stimulation induces mTOR signaling via an ERK-independent mechanism: implications for a direct activation of mTOR by phosphatidic acid. PLoS One 7: e47258, 2012. 